\title{
Studi Kasus: Asuhan Keperawatan Jiwa Pada Tn. A Dengan Masalah Harga Diri Rendah
}

\section{Fahrini Syafitri}

\author{
Fahrinisyafitri02@gmail.com
}

\section{BAB 1 \\ PENDAHULUAN}

\subsection{Latar belakang}

Kesehatan jiwa diartikan sebagai keadaan sejahtera, dimana individu memiliki kemampuan untuk menyadari potensi yang ada dalam dirinya, dapat mengatasi tekanan kehidupan yang terjadi, bekerja secara produktif dan dapat berkontribusi dalam komunitasnya. Individu yang sering mengalami tekanan emosional, distress dan terganggunya fungsi (disfungsi), akan berpotensi cukup besar mengalami gangguan jiwa yang dikenal dengan istilah orang dengan gangguan jiwa (ODGJ) (Rahayu \& Daulima, 2019)

Skizofrenia merupakan salah satu gangguan jiwa yang ada di indonesia. Menurut (Videbeck, 2015) Skizofrenia merupakan gangguan psikiatrik yang ditandai dengan disorganisasi pola pikir dimanifestasikan dengan masalah komunikasi. Gejala skizofrenia meliputi gejala positif dan gejala negatif. Gejala positif mencakup delusi, halusinasi, sedangkan gejala negatif seperti apatis, afek datar, hilangnya minat atau ketidakmampuan untuk melakukan aktivitas rutin, kemiskinan isi pembicaraan, gangguan dalam hubungan sosial, ditemukan pada pasien dengan harga diri rendah (Rahayu \& Daulima, 2019).

Berdasarkan data (WHO) sekitar 450 juta orang di dunia yang mengalami gangguan jiwa, sebagian besar mengalami skizofrenia. Di Indonesia sebanyak $84,9 \%$ pengidap skizofrenia di Indonesia telah berobat. Data dari 33 Rumah 
sakit jiwa yang ada di seluruh Indonesia menyebutkan hingga kini jumlah penderita gangguan jiwa berat mencapai 2,5 juta orang (Riskesdas, 2018). Di Sumatera Utara sendiri penderita skizofrenia menduduki peringkat ke 21 dengan nilai privalensi 6,3\%, setelah Provinsi Timur (Kemenkes, 2019). Gejala negatif dari skizofrenia termasuk harga diri rendah (Pardede, Hamid \& Putri, 2020)

Harga diri rendah merupakan salah satu respon maladaptif dalam rentang respon neurobiologi. Proses terjadinya harga diri rendah kronik pada pasien skizofrenia dapat dijelaskan dengan menganalisa stressor predisposisi dan presipitasi yang bersifat biologis, psikologis, dan sosial budaya sehingga menghasilkan respon bersifat maladaptif yaitu perilaku harga diri rendah kronik.Respon terhadap stressor pada pasien harga diri rendah memunculkan respon secara kognitif, afektif, fisiologis, perilaku dan sosial. Respon-respon tersebut akan dianalisis lebih lanjut, sehingga memunculkan rentang respon (Pardede, Keliat, \& Yulia, 2015). Sedangkan harga diri yang tinggi digambarkan dari sifat individu yang memiliki perasaan penerimaan diri tanpa syarat, meski salah, kalah dan gagal, sebagai yang berharga dan sifat penting untuk dirinya sendiri. Individu yang memiliki perasaan tidak berharga, tidak berarti, dan harga diri rendah yang berkepanjangan karena evaluasi negatif terhadap diri mereka sendiri dan diri mereka sendiri kemampuan merupakan gambaran seseorang yang memiliki harga diri yang rendah (Pardede \& Laia, 2020).

Dalam hal kondisi faktor penyebab dari gangguan harga diri yang pertama yaitu faktor predisposisi meliputi faktor yang mempengaruhi harga diri seperti penolakan dari orang tua, harapan dan ideal diri yang tidak bisa tercapai, selalu menemui kegagalan, tanggung jawab personal yang kurang serta ketergantungan terhadap orang lain, faktor performa peran seperti peran gender, tuntutan kerja dan budaya yang dapat mempengaruhi, sedangkan faktor 
identitas diri meliputi tekanan yang disebabkan dari orang - orang terdekat seperti orang tua yang kurang percaya akan dirinya, tekanan dari kelompok sebaya dan perubahan struktur sosial, yang kedua yaitu faktor stresr pencetus dapat terjadi diakibatkan oleh truma seperti pskosial atau ancaman yang dapat mengganggu kehidupan, ketegangan peran yang mengakibatkan individu frustasi atas posisi yang didapatkan. Dengan gangguan harga diri, seseorang akan menghadapi suasana hati dan ingatan tentang masa lalu yang negatif dan lebih rentan mengalami depresi ketika menghadapi stress karena pola pikir yang buruk tentang masa lalu yang negatif dan lebih rentan mengalami depresi ketika menghadapi stress karena pola pikir yang buruk tentang diri sendiri, tujuan hidup yang tidak jelas, dan masa depan yang lebih pesimis, semakin rendah harga diri seseorang akan lebih berisiko terkena gangguan kepribadian (Pardede, 2017)

Upaya yang dapat dilakukan untuk meningkatkan kemampuan berinteraksi pada pasien yang mengalami harga diri rendah adalah dukungan keluarga. Dukungan keluarga merupakan bentuk pemberian dukungan terhadap anggota keluarga lain yang mengalami permasalahan, yaitu memberikan dukungan pemeliharaan, emosional untuk mencapai kesejahteraan anggota keluarga dan memenuhi kebutuhan psikososial. Pasien harga diri rendah biasanya memiliki lebih dari satu masalah keperawatan. Sejumlah masalah pasien akan saling berhubungan dan dapat digambarkan sebagai pohon masalah (Elvidiana \& Fitriani, 2019).

Dalam hal ini peran fungsi dan tanggung jawab perawat psikiatri dalam meningkatkan derajat kesehatan jiwa, dalam kaitannya dengan menarik diri adalah meningkatkan percaya diri pasien dan mengajarkan untuk berinteraksi dengan orang lain, misalnya berkenalan dan bercakap-cakap dengan pasien lain, memberikan pengertian tentang kerugian menyendiri dan keuntungan dari 
berinteraksi dengan orang lain, sehingga diharapkan mampu terjadi peningkatan interaksi sosial pasien.

Survei awal dilakukan di Rumah Sakit yang ditemukan 30 orang yang terdiagnosa skizofrenia dengan masalah gangguan konsep diri : harga diri rendah orang dan Tn.A yang menjadi pasien kelolaan yang diberikan asuhan keperawatan jiwa.

\subsection{Tujuan Penulisan}

\subsubsection{Tujuan Umum}

Mahasiswa mampu memberikan Asuhan Keperawatan Jiwa Pada Tn. A Dengan Harga Diri Rendah”.

\subsubsection{Tujuan Khusus}

1. Mahasiswa mampu Melakukan Pengkajian Asuhan Keperawatan Jiwa Pada Tn. A Dengan Harga Diri Rendah”

2. Mahasiswa mampu Merumuskan Diagnosa Asuhan Keperawatan Jiwa Pada Tn. A Dengan Harga Diri Rendah”

3. Mahasiswa mampu Menentukan Intervensi Asuhan Keperawatan Jiwa Pada Tn. A Dengan Harga Diri Rendah”

4. Mahasiswa mampu Melakukan Implementasi Asuhan Keperawatan Jiwa Pada Tn. A Dengan Harga Diri Rendah”

5. Mahasiswa mampu Melakukan Evaluasi Asuhan Keperawatan Jiwa Pada Tn. A Dengan Harga Diri Rendah”

6. Mahasiswa mampu melakukan pendokumentasian Asuhan Keperawatan Jiwa Pada Tn. A Dengan Harga Diri Rendah”

\section{BAB 2}

\section{TINJAUAN TEORITIS}




\subsection{Konsep Harga Diri Rendah}

\subsubsection{Definisi}

Harga diri rendah adalah disfungsi psikologis yang meluas dan terlepas dari spesifiknya. Masalahnya, hampir semua pasien menyatakan bahwa mereka ingin memiliki harga diri yang lebih baik. Jika kita hanya mengurangi harga diri rendah, banyak masalah psikologis akan berkurang atau hilang secara substansial sepenuhnya. Harga diri merupakan komponen psikologis yang penting bagi kesehatan. Banyak penelitian sebelumnya menunjukkan bahwa harga diri yang rendah sering kali menyertai gangguan kejiwaan. Harga diri yang tinggi dikaitkan dengan kecemasan yang rendah, efektif dalam kelompok dan penerimaan orang lain terhadap dirinya, sedangkan masalah kesehatan dapat menyebabkan harga diri, sehingga harga diri dikaitkan dengan hubungan interperonal yang buruk dan beresiko terjadinya depresisehingga perasaan negatif mendasari hilangnya kepercayaan diri dan harga diri individu dan menggambarkan gangguan harga diri (Wijayati et al., 2020).

Harga diri rendah berasal dari pengalaman seseorang seiring dengan pertumbuhannya, seperti : tidak ada kasi sayang, dorogan dan tantangan, tidak terdapat cinta dan penerimaan, selalu mengalami kritikan, ejekan, sarkame, dan sinisme, adanya pemukulan fisik dan pelecehan tidak adanya pengakuan dan pujian untuk prestasi, terdapat kelebihan dan keunikan yang selalu di abaikan (Pardede, Hafizudin, \& Sirait, 2021). Harga diri rendah merupakan perasaan tidak berharga, tidak berarti, dan rendah diri yang berkepanjangan akibat evaluasi negatif terhadap diri sendiri dan kemampuan diri (Keliat dkk, 2011; Pardede, 2019) 
Harga diri yang tinggi dikaitkan dengan kecemasan yang rendah, efektif dalam kelompok dan penerimaan orang lain terhadap dirinya, sedangkan masalah kesehatan dapat menyebabkan harga diri, sehingga harga diri dikaitkan dengan hubungan interperonal yang buruk dan beresiko terjadinya depresisehingga perasaan negatif mendasari hilangnya kepercayaan diri dan harga diri individu dan menggambarkan gangguan harga diri. Harga diri rendah dapat digambarkan sebagai perasaan negatif terhadap diri sendiri termasuk hilangnya percaya diri dan harga diri. Harga diri rendah dapat terjadi secara situasional (trauma) atau kronis (negatif self evaluasi yang telah berlangsung lama). Dan dapat di ekspresikan secara langsung atau tidak langsung (nyata atau tidak nyata)(Samosir, 2020)

Berdasarkan defenisi diatas dapat disimpulkan bahwa harga diri rendah adalah perasaan tidak berharga, tidak berarti dan rendah diri yang berkepanjangan akibat evaluasi yang negatif terhadap diri sendiri atau kemampuan diri. Adanya perasaan hilang kepercayaan diri, merasa gagal karena tidak mampu mencapai keinginan sesuai dengan ideal diri.

\subsubsection{Etiologi}

Harga diri rendah situasional disebabkan karena adanya ketidakefektifan koping individu akibat kurangnya umpan balik yang positif. Penyebab harga diri rendah juga dapat terjadi pada masa kecil sering disalahkan, jarang diberi pujian atas keberhasilannya. Saat individu mencapai masa remaja keberadaannya kurang dihargai, tidak diberi kesempatan dan tidak diterima. Menjelang dewasa awal sering gagal disekolah, pekerjaan atau pergaulan. Menurut NANDA (2017) faktor yang mempengaruhi harga diri rendah meliputi faktor Predisposisi dan faktor Presipitasi yaitu :

\section{Faktor Predisposisi}

a. Faktor yang mempengaruhi harga diri meliputi penolakan orang tua, harapan orang tua yang tidak realistis, kegagalan yang berulang, 
kurang mempunyai tanggung jawab personal, ketergantungan pada orang lain, dan ideal diri yang tidak realistis.

b. Faktor yang mempengaruhi performa peran adalah stereo type peran gender, tuntutan peran kerja, dan harapan peran budaya.

c. Faktor yang mempengaruhi identitas pribadi meliputi ketidakkepercayaan orang tua, tekanan dari kelompok sebaya, dan perubahan struktur sosial.

\section{Faktor Presipitasi}

Faktor presipitasi terjadi haga diri rendah biasanya adalah kehilangan bagian tubuh, perubahan penampilan/bentuk tubuh, kegagalan atau produktifitas yang menurun. Secara umum, ganguan konsep diri harga diri rendah ini dapat terjadi secara stuasional atau kronik. Secara situasional karena trauma yang muncul secara tiba-tiba, misalnya harus dioperasi, kecelakaan, perkosaan atau dipenjara. Termasuk dirawat dirumah sakit bisa menyebabkan harga diri rendah disebabkan karena penyakit fisik atau pemasangan alat bantu yang membuat klien tidak nyaman (Yosep, 2016).

\section{Perilaku}

Pengumpulan data yang dilakukan oleh perawat meliputi perilaku yang objektif dan dapat diamati serta perasaan subjektif dan dunia dalam diri klien sendiri. Perilaku yang berhubungan dengan harga diri rendah salah satunya mengkritik diri sendiri, sedangkan keracuan identitasseperti sifat kepribadian yang bertentangan serta depersonalisasi (Stuart, 2018)

\subsubsection{Tanda Dan Gejala}

Menurut Saptina, (2020) tanda dan gejala pada harga diri rendah yaitu:

1. Data Subjektif

a. Mengintrospeksi diri sendiri. 
b. Perasaan diri yang berlebihan.

c. Perasaan tidak mampu dalam semua hal.

d. Selalu merasa bersalah

e. Sikap selalu negatif pada diri sendiri.

f. Bersikap pesimis dalam kehidupan.

g. Mengeluh sakit fisik.

h. Pandangan hidup yang terpolarisasi.

i. Menentang kemampuan diri sendiri.

j. Menjelek-jelekkan diri sendiri.

k. Merasakan takut dan cemas dalam suatu keadaan.

1. Menolak atau menjauh dari umpan balik positif.

m. Tidak mampu menentukan tujuan.

2. Data Obyektif

1. Produktivitas menjadi menurun.

2. Perilaku distruktif yang terjadi pada diri sendiri.

3. Perilaku distruktif yang terjadi pada orang lain.

4. Penyalahgunaan suatu zat.

5. Tindakan menarik diri dari hubungan sosial.

6. Mengungkapkan perasaan bersalah dan malu.

7. Muncul tanda depresi seperti sukar tidur dan makan.

8. Gampang tersinggung dan mudah marah.

\subsubsection{Rentang Respon}

Konsep diri merupakan aspek kritikal dan dasar dari perilaku individu. Individu dengan konsep diri yang positif dapat berfungsi lebih efektif yang terlihat dari kemampuan interpersonal, kemampuan intelektual dan penguasaan lingkungan. Konsep diri yang negatif dapat dilihat dari hubungan individu an sosial yang maladaptif. 
Gambar Rentang respon konsep - diri ( Stuart G.W, 2018)

Respon Adaptif
Aktualisasi diri Konsep diri Harga diri kerancuan identitas Depersonalisasi
Positif Rendah

Aktualisasi diri adalah pernyataan diri tentang konsep diri yang positif dengan latar belakang pengalaman nyata yang sukses dan dapat diterima. Konsep diri positif merupakan bagaimana seseorang memandang apa yang ada pada dirinya meliputi citra dirinya. Ideal dirinya harga dirinya, penampilan peran serta identitas dirinya secara positif. Hal ini akan menunjukan bahwa individu itu akan menjadi individu yang sukses.

Harga diri rendah Situasional merupakan perasaan negatif terhadap dirinya sendiri, termasuk kehilangan percaya diri, tidak berharga, tidak, berguna, pesimis tidak ada harapan dan putus asa. Adapun perilaku yang berhubungan dengan harga diri yang rendah yaitu mengkritik diri sendiri atau orang lain, penurunan produktivitas, destruktif yang diarahkan kepada orang lain, ganguan dalam berhubungan, perasaan tidak mampu, rasa bersalah, perasaan negatif mengenai tubuhnya sendiri, keluhan fisik, menarik diri secara sosial, khawatir, serta menarik diri dari realitas.

Keracuan identitas merupakan suatu kegagalan individu untuk mengintegrasikan berbagai identifikasi masa kanak-kanak kedalam kepribadian psikososial dewasa yang harmonis. Adapun perilaku yang berhubungan dengan keracuan identitas yaitu tidak ada kode moral, sifat kepribadian yang bertentangan, hubungan interpersonal eksploitatif, perasaan hampa. Perasaan mengambang tentang diri sendiri, tingkat ansietas yang tinggi, ketidak mampuan untuk empati terhadaapa orang lain. 
Despersonalisasi merupakan suatu perasaan yang tidak realistis dimana klien tidak dapat membedakan stimulus dari dalam atau luar dirinya. Individu mengalami kesulitan untuk membedakan dirinya sendiri dari orang lain, dan tubuhnya sendiri merasa tidak nyata dan asing baginya.

\subsubsection{Proses Terjadinya HDR Stresor}

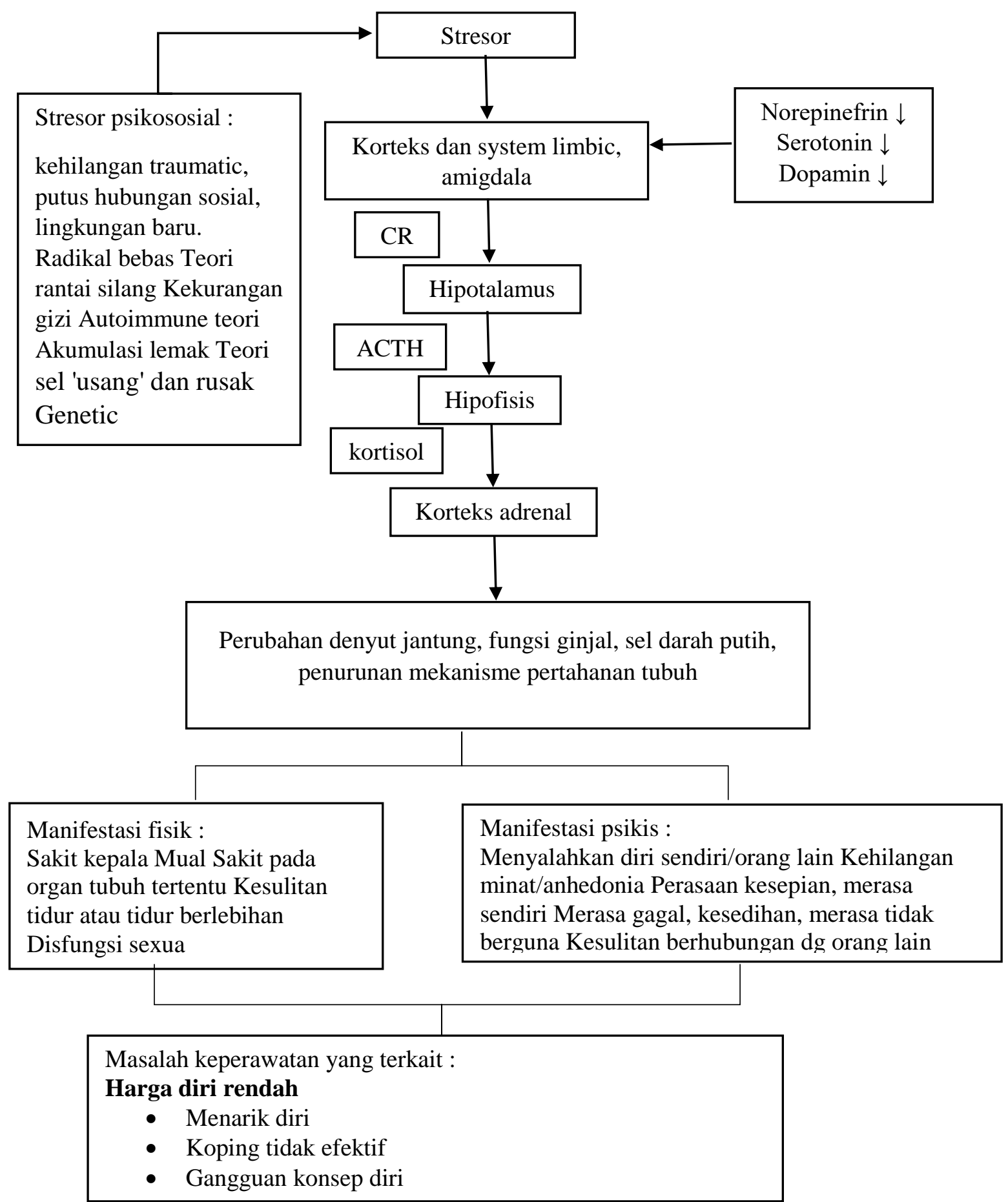




\subsubsection{Karakteristik}

a. Mengatakan hal yang negatif tentang diri sendiri dalam waktu lama dan terus menerus

b. Mengekspresikan sikap malu/ minder/ rasa bersalah

c. Kontak mata kurang/ tidak ada

d. Selalu mengatakan ketidak mampuan/kesulitan untuk mencoba sesuatu

e. Bergantung pada orang lain

f. Tidak asertif

g. Pasif dan hipoaktif

h. Bimbang dan ragu-ragu

i. Menolak umpan balik positif dan membesarkan umpan balik negatif mengenai dirinya

Faktor yang berhubungan

a. Sikap keluarga yang tidak mendukung

b. Penolakan

c. Kegagalan

Untuk menegakkan diagnosa ini perlu didapatkan data utama
a. Kontak mata kurang/tidak ada
b. Mengungkapkan secara verbal rasa minder/malu/bersalah
c. Mengatakan hal yang negatif tentang diri sendiri
d. Sering mengatakan ketidakmampuan melakukan sesuatu 


\subsubsection{Pohon Masalah}

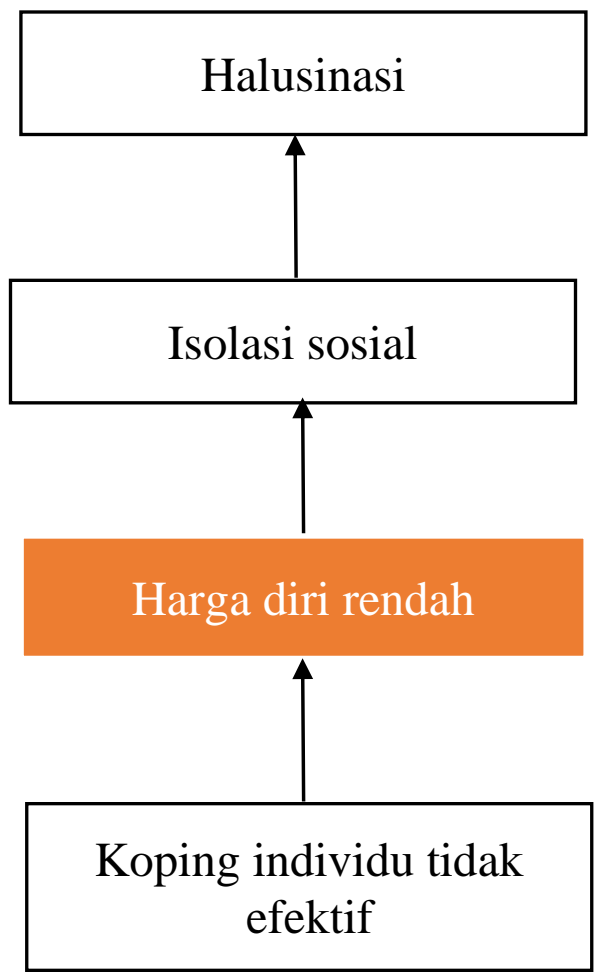

\subsubsection{Faktor Predisposisi dan Faktor Presipitasi Harga Diri Rendah}

Menurut (Suryani \& Efendi, 2020)fakor predisposisi dan faktor presipitasi harga diri rendah ialah :

1. Aspek Biologis Sebagian besar pasien memiliki riwayat gangguan jiwa sebelumnya (75\%), Sebagian kecil memiliki riwayat genetik (25\%). Faktor genetik berperan dalam mencetuskan terjadinya gangguan jiwa pada diri seseorang. Sadock dan Sadock (2007) menyampaikan bahwa genetik memiliki peran pada pasien skizofrenia. Seseorang beresiko $10 \%$ jika salah satu orang tua menderita gangguan dan jika kedua orang tua memiliki riwayat gangguan maka resiko akan lebih besar, yaitu menjadi $40 \%$.

2. Aspek Psikologis Pasien HDR kronis yang diberikan terapi kognitif memiliki riwayat psikologis kurang percaya diri (90\%). Menurut Stuart (2016) bahwa faktor psikologis meliputi konsep diri, intelektualitas, 
kepribadian, moralitas, pengalaman masa lalu, koping dan keterampilan komunikasi secara verbal mempengaruhi perilaku seseorang dalam hubungannya dengan orang lain.

3. Aspek Sosial Budaya Pasien yang diberikan terapi kognitif dan psikoedukasi keluarga memiliki masalah sosial budaya yang sangat berpengaruh yaitu tidak memiliki teman (85\%), konflik keluarga (80\%) dan status ekonomi rendah (70\%). Townsend (2009) menyatakan bahwa status sosioekonomi yang rendah lebih banyak mengalami gangguan jiwa dibandingkan tingkat sosio ekonomi tinggi.

\subsubsection{Manifestasi Klinis Harga Diri Rendah}

Tanda dan gejala harga diri rendah

1. Perasaan malu terhadap diri sendiri akibat adanya penyakit atau akibat tindakan terhadap penyakit.

2. Rasa bersalah terhadap diri sendiri. Individu merasa tidak mampu dan tidak berguna dan memandang dirinya lemah.

3. Gangguan hubungan sosial, seperti menarik diri dari masyarakat. Individu merasa tidak berguna sehingga klien merasa lebih suka meyendiri dan enggan untuk berinteraksi dengan lingkungan masyarakat.

4. Merendahkan martabat. Individu merasa dirinya lemah merasa bodoh, merasa tidak mampu dalam melakukan segala hal, dan individu merasa tidak tahu apa-apa, mengabaikan bahkan menolak kemampuan yang dimiliki sehingga produktivitas individu menurun.

5. Percaya diri kurang. Individu merasa ragu-ragu dalam mengambil keputusan, individu tidak memiliki rasa percaya pada dirinya dan individu selalu memandnag dirinya negatif.

6. Mencederai diri sendiri dan orang lain. Akibat harga diri rendah individu memandang hidupnya pesimis, tidak berguna sehingga terdorong untuk merusak atau mengakhiri hidupnya. Bahkan klien dengan harga diri 
rendah timbul perasaan benci dan dapat menimbulkan perilaku kekerasan terhadap lingkungan sekitar

\subsubsection{Proses Terjadinya Harga Diri Rendah}

Harga diri rendah kronis terjadi merupakan proses kelanjutan dari harga diri rendah situasional yang tidak terselesaikan. Atau dapat juga terjadi karena individu tidak pernah mendapat feed back dari lingkungan tentang prilaku klien sebelumnya bahkan kecendrungan lingkungan yang selalu memberi respon negatif mendorong individu menjadi harga diri rendah. Harga diri rendah kronis terjadi disebabkan banyak faktor. Awalnya individu berada pada suatu situasi yang penuh dengan stressor (krisis), individu berusaha menyelesaikan krisis tetapi tidak mampu atau merasa gagal menjalankan fungsi dan peran. Penilaian individu terhadap diri sendiri karena kegagalan menjalankan fungsi dan peran adalah kondisi harga diri rendah situasional, jika lingkungan tidak memberi dukungan positif atau justru menyalahkan individu dan terjadi secara terus menerus akan mengakibatkan individu mengalami harga diri rendah kronis(Samosir, 2020)

\subsection{Konsep Asuhan Keparawatan Jiwa}

Adapun konsep asuhan keperawatan harga diri rendah menurut (Yusuf, 2015), adalah sebagai berikut:

\subsubsection{Data Pengkajian}

1. Faktor Predisposisi

\section{Biologi}

a. Genetik : riwayat adanya trauma yang menyebabkan lesi pada daerah frontal, temporal dan limbic, pada anak yang kedua orangtuanya tidak menderita, kemungkinan terkena penyakit adalah $1 \%$. Sementara pada anak yang salah satu orangtuanya menderita kemungkinan terkena adalah 13\%. Dan jika kedua orangtuanya penderita maka resiko terkena adalah $35 \%$, riwayat 
janin pada saat prenatal dan perinatal meliputi trauma, penurunan oksigen pada saat melahirkan, prematur, preeklamsi, malnutrisi, stres, ibu perokok, alkohol, pemakaian obat-obatan, infeksi, hipertensi dan agen teratogenik

b. Nutrisi : adanya riwayat gangguan nutrisi ditandai dengan penurunan $\mathrm{BB}$, rambut rontok, anoreksia, bulimia nervosa,

c. Keadaan kesehatan secara umum : riwayat kesehatan umum, misalnya kurang gizi, kurang tidur, gangguan irama sirkadian, kelemahan, infeksi

d. Sensitivitas biologi : riwayat penggunaan obat, riwayat terkena infeksi dan trauma, radiasi dan riwayat pengobatannya

e. Paparan terhadap racun : paparan virus influenza pada trimester 3 kehamilan, riwayat keracunan $\mathrm{CO}$, asbestos

\section{Psikologis}

a. Intelegensi : riwayat kerusakan struktur di lobus frontal dimana lobus tersebut berpengaruh kepada proses kognitif, suplay oksigen terganggu dan glukosa

b. Ketrampilan verbal :gangguan keterampilan verbal akibat faktor komunikasi dalam keluarga, seperti : komunikasi peran ganda, tidak ada komunikasi, komunikasi dengan emosi berlebihan, komunikasi tertutup, riwayat kerusakan yang mempengaruhi fungsi bicara, misalnya Stroke, trauma kepala

c. Moral : riwayat tinggal di lingkungan yang dapat mempengaruhi moral individu, misalnya lingkungan keluarga yang broken home, konflik, Lapas.

d. Kepribadian : mudah kecewa, kecemasan tinggi, mudah putus asa, menutup diri

e. Pengalaman masa lalu : orangtua yang otoriter, orangtua yang selalu membandingkan, konflik orangtua, anak yang dipelihara 
oleh ibu yang suka cemas, terlalu melindungi, dingin dan tak berperasaan, ayah yang mengambil jarak dengan anaknya, penolakan atau tindakan kekerasan dalam rentang hidup klien, penilaian negatif yang terus menerus dari orang tua

f. Konsep diri : ideal diri yang tidak realistis, identitas diri tak jelas, harga diri rendah, krisis peran, gambaran diri negatif

g. Motivasi :riwayat kurangnya penghargaan, riwayat kegagalan

h. Pertahanan psikologi : ambang toleransi terhadap stress rendah, riwayat gangguan perkembangan

i. Self control : riwayat tidak bisa mengontrol stimulus yang datang, misalnya suara, rabaan, penglihatan, penciuman, pengecapan, gerakan.

\section{Sosiokultural}

a. Usia : riwayat tugas perkembangan yang tidak selesai

b. Gender : riwayat ketidakjelasan identitas, riwayat kegagalan peran gender,

c. Pendidikan : pendidikan yang rendah, riwayat putus dan gagal sekolah,

d. Pendapatan : penghasilan rendah

e. Pekerjaan : pekerjaan stresful, Pekerjaan beresiko tinggi

f. Status sosial : tuna wisma, Kehidupan terisolasi

g. Latar belakang Budaya : tuntutan sosial budaya seperti paternalistik, stigma masyarakat

h. Agama dan keyakinan : riwayat tidak bisa menjalankan aktivitas keagamaan secara rutin, rutin, kesalahan persepsi terhadap ajaran agama tertentu

i. Keikutsertaan dalam politik : riwayat kegagalan dalam politik 
j. Pengalaman sosial : perubahan dalam kehidupan, mis bencana, perang, kerusuhan, dll, tekanan dalam pekerjaan, kesulitan mendapatkan pekerjaan,

k. Peran social : isolasi sosial khususnya untuk usia lanjut, stigma yang negatif dari masyarakat, diskriminasi, stereotype, praduga negatif

\section{Faktor Presipitasi}

1. Biologi : genetic, nutrisi, keadaan kesehatan secara umum, sensitivitas biologi, paparan terhadap racun.

2. Psikologis : intelegensi, ketrampilan verbal, moral, kepribadian, pengalaman masa lalu, konsep diri, motivasi, pertahanan psikologi, self control.

3. Sosiokultural : usia, gender, pendidikan, pendapatan, pekerjaan, status social, latar belakang Budaya, agama dan keyakinan, keikutsertaan dalam politik, pengalaman sosial, peran sosial

4. Penilaian terhadap stresor

Penilaian terhadap stresor dapat dikaji dari berbagai sisi, dimulai dari segi kognitif yaitu apa yang dipikirkan klien tentang stresor yang dialaminya, dari segi afekti yaitu bagaimana perasaannya, dari segi fisiologis yaitu bagaimana perubahan fisik yang terjadi akibat stresor, dari segi perilaku yaitu bagaimana perilaku yang ditampilkan terkait stresor dan dari sesi sosial yaitu bagaimana hubungan klien dengan orang lain terkait stresor yang dialaminya.

\section{Sumber Koping}

Kondisi status ekonomi, kemampuan menyelesaikan masalah, dukungan sosial, dan keyakinan budaya. 


\section{Mekanisme Koping}

Menurut Stuart (2018) mekanisme kopng termasuk pertahanan koping jangka pendek atau jangka panjang serta penggunaan mekanisme pertahanan ego untuk melindungi diri sendiri dalam menghadapi persepsi diri yang menyakitkan. Pertahanan tersebut mencakup berikut ini:

1) Aktivitas yang memberikan pelarian sementara dari krisis identitas diri (misalnya, konser musik, bekerja keras, menonton televise secara obsesif)

2) Aktivitas yang memberikan identitas pengganti sementara (misalnya dalam club sosial, agama, politik, kelompok, gerakan atau geng).

3) Aktivitas yang sementara menguatkan atau meningkatkan perasaan diri yang tidak menentu (misalnya, olahraga yang kompetitif, prestasi akademik, kontes untuk mendapatakan popularitas).

Pertahanan jangka panjang mencakup berikut ini:

1) Penutupan identitas: adopsi identitas premature yang diinginkan oleh orang terdekat tanpa memerhatikan keinginan, aspirasi, atau potensi diri individu.

2) Identitas negatif: asumsi identitas yang tidak sesuai dengan nilai dan harapan yang diterima masyarkat.

\subsubsection{Diagnosis Keperawatan Jiwa}

Perawat kesehatan jiwa menganalisis data pengkajian dalam menentukan diagnosis. Landasan untuk memberikan asuhan keperawatan kesehatan jiwa adalah pengenalan dan mengidentifikasi pola respons terhadap masalah kesehatan jiwa atau penyakit psikiatri yang actual dan pontensial 


\subsubsection{Perencanaan}

Perawat kesehatan jiwa mengembangkan rencana asuhan yang menggambarkan intervensi untuk mencapai hasil yang diharapkan. Rencana asuhan digunakan untuk memandu intervensi terapeutik secara sistematis dan mencapai hasil pasien yang diharapkan.

\subsubsection{Tindakan Keperawatan}

1. Tindakan keperawatan pada pasien:

1) Tujuan:

a) Pasien dapat mengindentifikasi kemampuan dan aspek positif yang di miliki.

b) Pasien dapat menilai kemampuan yang dapat di gunakan.

c) Pasien dapat menetaptan/memilih kegiatan yang sesuai kemampuan.

d) Pasien dapat melatih kegiatan yang sudah dipilih, sesuai kemampuan.

e) Pasien dapat menyusun jadwal untuk melakukan kegiatan yang sudah dilatih.

\section{Tindakan Keperawatan}

1) Mengindentifikasi kemampuan dan aspek positif yang yang masih di miliki pasien. Untuk membantu pasien dapat mengungkapkan kemempiuan dan aspek positif yang masih dimilikinya, perawat dapat:

a. Mendiskusikan bahwa sejumlah kemampuan dan aspek positif yang dimiliki pasien seperti kegiatan pasien di rumah sakit, dalam keluarga dan lingkungan adanuya keluarga dan lingkungan terdekat pasien

b. Beri pujian yang realistik/nyata dan hindarkan setiap kali bertemu dengan pasien penilaian yang negative

2) Membantu pasien menilain kemampuan yang dapat digunakan. 
Untuk tindakan tersebut saudara dapat :

a Mendiskusikan dengan pasien kemempuan yang masih dapatb digunakan saat ini.

b. Bantu pasien menyebutkanya dan memberi penguatan terhadap kemampuan diri yang diungkapkan pasien.

c. Perlihatkan respon yang kondusif dan menjadi pendengar yang aktif.

3) Membantu pasien memilih atau menetapkan kemampuan yang akan dilatih Tindakan keperawatan yang dapat dilakukan adalah:

a. Mendiskusikan dengan pasien beberapa kegiatan yang dapat dilakukan dan dipilih sebagai kegiatan yang akan pasien lakukan sehari-hari

b. Bantu pasien menentukan kegiatan mana yang dapat pasien lakukan secara mandiri, mana kegiatan yang memerlukan bantuan minimal dari keluraga atau lingkungan terdekat pasien berikan contoh pelaksanakan kegiatan yang dilakukan pasien. Susun bersama pasien dan buat daftar kegitan seharihari pasien.

4) Melatih kemampuan yang dimiliki pasien.

Tindakan keperawatan tersebut saudara dapat melakukan:

a. Mendiskusikan dengan pasien untuk melatih kemampuan yang dipilih

b. Bersama pasien memperagakan kegiatan yang ditetapkan

c. Berika dukungan dan pujian pada setiap kegiatan yang dapat dilakukan pasien.

5) Membantu menyusun jadwal pelaksanaan kemampuan yang dilatih

Untuk mencapai tujuan tindakan keperawatan tersebut saudara 
dapat melakukan hal-hal berikut:

a. Memberi kesempatan pada pasien untuk mencoba kegiatan yang telah dilatihkan.

b. Beri pujian atas kegiatan - kegiatan yang dapat dilakukan pasien setiap hari

c. Susun jadwal untuk melaksanakan kegiatan yang telah dilatih.

d. Berikan kesempatan mengungkapkan perasaanya setelah pelaksanaanya kegiatan.

\section{Konseling}

Perawat kesehatan jiwa menggunakan intervensi konseling untuk membantu pasien meningkatkan atau memperoleh kembali kemampuan koping, memelihara kesehatan mental, dan mencegah penyakit atau ketidak mampuan menta (Yusuf et. al, 2015).

\section{Terapi Lingkungan}

Perawat kesehatan jiwa memberikan, membentuk, serta mempertahankan suatu lingkungan yang terapeutik dalam kolaborasinya dengan pasiendan pemberian pelayanan kesehatan lain.

\section{Aktivitas Asuhan Mandiri}

Perawat kesehatan jiwa membentuk intervensi sekitar aktivitas kehidupan sehari-hari pasien untuk memelihara asuhan mandiri dan kesejhteraan jiwa dan fisik

6. Intervensi psikobiologis

Perawat kesehatan jiwa menggunakan pengetahuan intervensi psikobiologis dan menerapkan keterampilan klinis untuk memulihkan kesehatan pasien dan mencegah ketidakmapuan lebih lanjut 
7. Penyuluhan kesehatan

Perawat kesehatan jiwa, melalui penyuluhan kesehatan, serta membantu pasien dalam mencapai pola kehidupanyang memuaskan produktif dan sehat.

8. Manajemen kasus

Perawat kesehatan jiwa menyajikan manejemen kasus untuk mengkordinasi kesehatan yang komprehensif serta memastikan kesenambungan asuhan.

9. Pemeliharaan dan peningkatan kesehatan Perawat kesehatan jiwa menerapkan strategi dan intervensi untuk meningkatkan, memelihara kesehatan jiwa, serta mencegah penyakit jiwa.

\section{Psikoterapi}

Spesialis yang bersetifikasi dalam keperawatan kesehatan jiwa menggunakan psikoterapi individu, psikoterapi kelompok, psikoterapi keluarga, psikoterapi anak, serta pengobatan terapeutik lain untuk membantu pasien untuk memelihara kesehatan jiwa, mencegah penyakit jiwa dan ketidakmampuan, serta memperbaiki atau mencapai kembali status kesehatan dan kemampuan fungsional pasien.

\section{Preskripsi Agen Farmakologis}

Spesialis yang bersertifikasi memberikan konsultasi kepada pemberi pelayanan kesehatan dan lainnya untuk memengaruhi rencana asuhan kepada pasien, dan memperkuat kemampuan yang lain untuk memberikan pelayanan kesehatan jiwa dan psikiatri serta membawa perubahan dalam setiap pelayanan kesehatan jiwa dan psikiatri 


\subsubsection{Evaluasi}

Perawat kesehatan jiwa mengevaluasi perkembangan pasien dalam mencapai hasil yang diharapkan. Asuhan keperawatan adalah proses dinamik yang melibatkan perusahaan dalam status kesehatan pasien sepanjang waktu, pemicu kebutuhan terhadap data baru, berbagai diagnosis, dan modifikisi rencana asuhan. Oleh karena itu, evaluasi merupakan suatu proses penilaian berkesinambungan tentang pengaruh intervensi keperawatan dan regimen pengobatan terhadap status kesehatan pasien dan hasil kesehatan yang diharapkan. 


\section{BAB 3}

\section{TINJAUAN KASUS}

\subsection{Identitas}

1. Klien Inisial

2. Jenis kelamin

3. Umur

4. Agama

5. Status

6. Tanggal pengkajian

7. RM No

8. Informent
: Tn. A

: Laki-Laki

: 13 Tahun

: islam

: belum menikah

: 28 Januari 2022

: 04-62-03

:Status klien dan komunikasi dengan klien

\subsection{Alasan Masuk Rumah Sakit}

Kurang lebih 7 bulan yang lalu klien berbica sendiri, berkelakukan aneh, melukai diri sendiri, tidak bisa tidur, gelisah, bingung, klien merasa malu karena tidak memiliki pekerja, ditinggal tunangannya, dan menyesal dengan perbuatannya yang telah merugikannya.

\subsection{Faktor Predisposisi}

Pasien sebelumnya tidak pernah ada riwayat gangguan jiwa. Pertama kali pasien mengalami gangguan jiwa ketika pasien mengalami peristiwa hilangnya alat kelamin pasien. Pasien juga mengatakan sering mendengar suara-suara yang menyuruh nya untuk memotong alat kelaminya demi keselamatan keluarga. pasien juga sempat menolak diajak berbicara dan berintraksi. Pasien juga sempat dibawa berobat kampung (dukun) tetapi tidak ada perubahan pada pasien tersebut, dan akhirnya keluarga memutuskan untuk membawa pasien ke rumah sakit jiwa. Ketika pasien dirawat di rumah sakit jiwa selama 3 hari pasien ingin meminta pulang kerumah. 


\subsection{Fisik}

Klien tidak memiliki keluhan fisik saat dilakukan tanda-tanda vital, didapatkan hasil TD : $113 / 74 \mathrm{mmHg} ; \mathrm{N} \quad: 88 \mathrm{x} / \mathrm{i} ; \mathrm{S} \quad: 36.5^{\circ} \mathrm{C} ; \mathrm{P} \quad: 20 \mathrm{x} / \mathrm{i}$; klien memiliki tinggi $160 \mathrm{~cm}$ dan berat badan $67 \mathrm{Kg}$

\subsection{Psikososial}

\section{Genogram}

Klien merupakan anak ke 2 dari 3 saudarah, 2 laki-laki dan 1 perempuan serta klien mengatakan orang tua kalian masih hidup

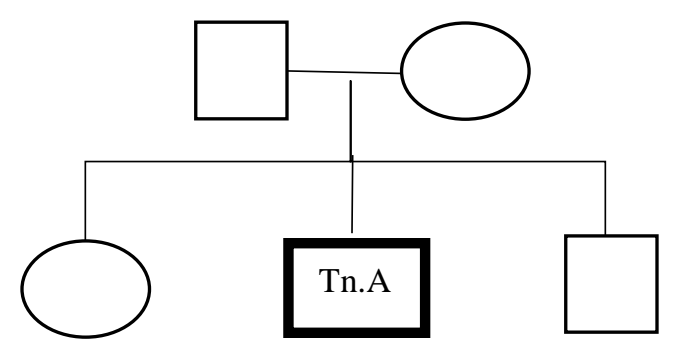

Klien mempunyai ayah satu dan ibu satu, serta mempunyai kakak satu, abang satu, klien adalah anak ke dua dari tiga bersaudara, klien mengalami gangguan jiwa dan keluarga dalam keadaan sehat fisik dan psikologis serta tidak mengalami gangguan jiwa (sehat jiwa).

Keterangan:

: perempuan

$\square$ : laki-laki

Z:Tn. A

$\square$ : garis keturunan

$L^{\prime}$ : garis perkawinan

_

$X$ : meningga 


\subsection{Konsep Diri}
a. Gambaran diri
: Klien tidak menyukai tubuhnya karena memiliki cacat
b. Identitas
: Klien anak ke 2 dari 3 bersaudara
c. Peran
: Klien berperan sebagai anak
d. Ideal diri
: Klien ingin cepat sembuh
e. Harga diri
: Klien merasa tidak berarti

\subsection{Hubungan Sosial}

1. Orang yang berarti : orang yang berarti dalam kehidupan pasien adalah keluarganya

2. Peran serta dalam kegiatan kelompok/masyarakat: Pasien tidak pernah mengikuti kegiatan kelompok lingkungan rumah

3. Hambatan dalam berbuhungan dengan orang Lain : klien tidak mudah akrab/ berhubungan dengan orang lain yang dia tidak kenal

\subsection{Spiritual}

1. Nilai dan Keyakinan : Klien beragama muslim

2. Kegiatan Ibadah : Klien jarang ibadah

\subsection{Status Mental}

1) Penampilan Klien

tampak kurang rapi dalam berpakaian

2) Pembicaraan

Klien masih mampu menjawab pertanyaan perawat dengan lambat dan jelas namun dapat dipahami

3) Aktivitas Motorik

Klien mengatakan bisa melakukan aktivitas sehari - hari. 
4) Suasana perasaan

Klien mengatakan merasa dibuang oleh keluarganya dan merasa minder dengan orang lain, klien mengatakan merasa malu karena tidak memiliki perkerjaan tetap Klien mengatakan tidak percaya dengan diri sendiri, Klien merasa tidak berguna karena tidak dapat membantu keluarga, klien tampak tidak percaya diri saat wawancara

Masalah keperawatan : Harga Diri Rendah

5) Afek

Afek wajah sesuai dengan topic pembicaraan

6) Interaksi

Selama wawancara Klien kooperatif saat wawancara

7) Persepsi

Klien mengatakan bahwa ia tidak dapat memproses cepat setiap orang berbicara atau bertanya padanya

8) Proses Pikir

Klien mampu menjawab apa yang ditanya dengan baik.

9) Isi pikir

Klien dapat mengontrol isi pikirnya,klien tidak mengalami gangguan isi pikir dan tidak ada waham. Klien tidak mengalami fobia, obsesi ataupun depersonalisasi.

10) Tingkat kesadaran

Klien tidak mengalami gangguan orientasi, klien mengenali waktu, orang dan tempat.

11) Memori

Klien mampu menceritakan kejadian di masa lalu dan yang pernah klien alami

12) Tingkat konsentrasi berhitung

Klien kurang berkonsentrasi dalam perhitungan sederhana dan tanpa harus di bantu orang lain.

13) Kemampuan penilaian 
Klien dapat membedakan hal yang baik dan yang buruk (mampu melakukan penilaian).

14) Daya tilik diri

Klien tidak mengingkari penyakit yang diderita, klien mengetahui bahwa dia sedang sakit

\subsection{Mekanisme Koping}

Klien mengalami mekanisme koping adaptif yaitu klien dapat berbicara cukup baik dengan orang lain.

\subsection{Masalah Psikososial dan Lingkungan}

Klien mengatakan sulit berteman dengan orang lain karena klien dan tidak sempat untuk melakukan kumpul-kumpul bersama masyarakat sekitar.

\subsection{Pengetahuan Kurang Tentang Gangguan Jiwa}

Klien tidak mengetahui tentang penyakit gangguan jiwa dan klien tidak tahu obat apa yang harus diminum untuk mengatasi gangguan jiwanya.

\subsection{Analisis Data}

\begin{tabular}{|c|c|}
\hline \multicolumn{1}{|c|}{ Data } & \multicolumn{1}{|c|}{ Masalah } \\
\hline DS : & \\
- Klien mengatakan tidak percaya dengan & \\
- kemampuan diri sendiri & Gangguan Konsep diri : Harga \\
Klien merasa tidak berguna karena tidak & Diri Rendah \\
- dapat membantu keluarga. & \\
Klien merasa minder karena keadaannya & \\
\hline
\end{tabular}




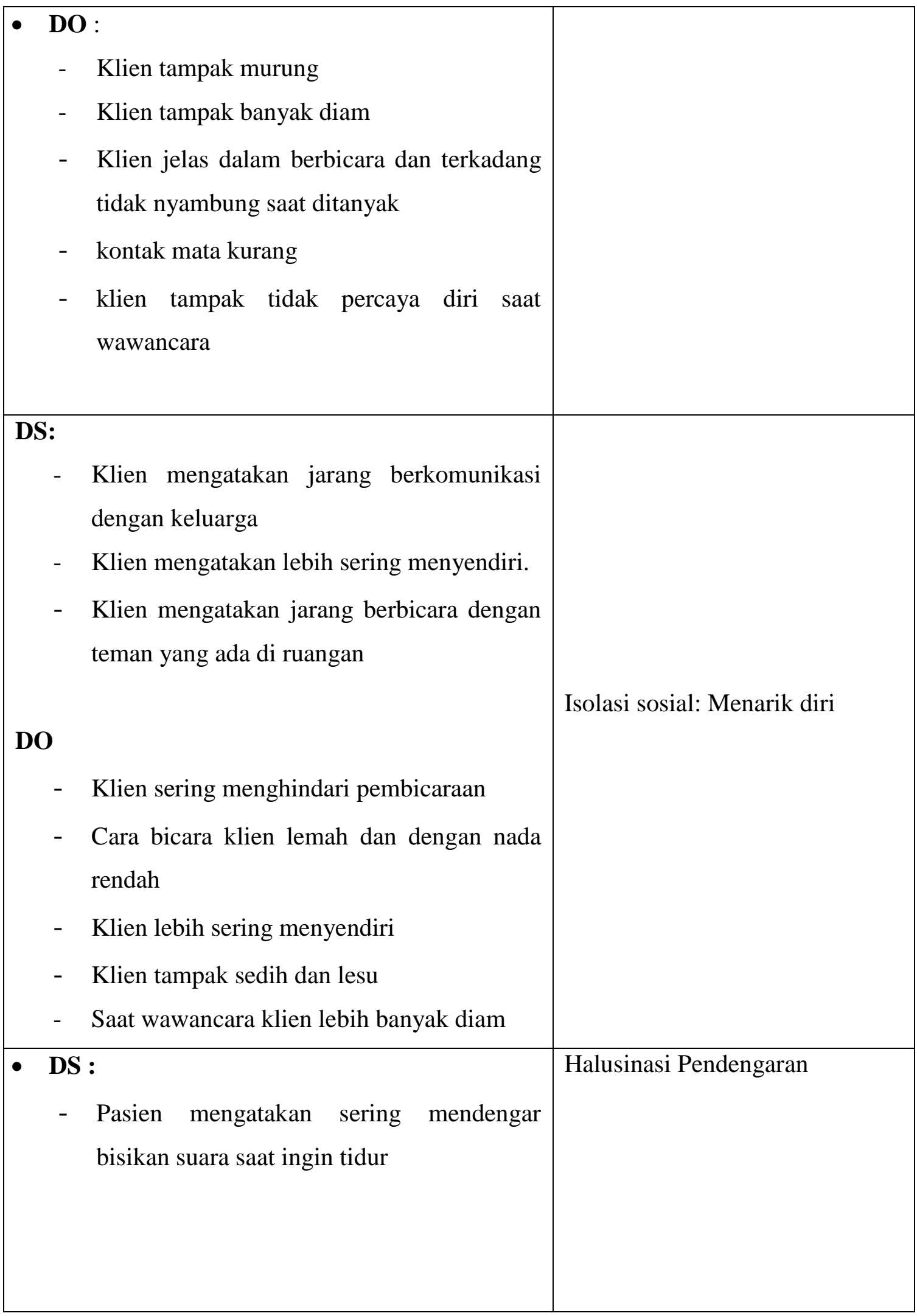


- Klien mengatakan mendengar suara-suara menyuruhnya untuk menyakiti diri sendiri dan berkata bahwa dia tidak berguna.

- Klien merasa gelisah dan takut jika mendengar suara tersebut

- Klien mengatakan bila suara- suara muncul secara tiba- tiba klien merasa takut

- DO:

- Klien tampak berbicara sendiri

- Klien terlihat senyum sendiri dan marahmarah saat sendirian.

- $\quad$ klien kurang konsentrasi

- $\quad$ klien tampak gelisah

- $\quad$ klien tampak sulit tidur

\subsection{Masalah Keperawatan}

- Isoalasi sosial : Menarik Diri

- Gangguan Konsep Diri : Harga Diri Rendah

- Gangguan Persepsi dan Sensori : Halusinasi Pendengaran 


\subsection{Pohon Masalah}

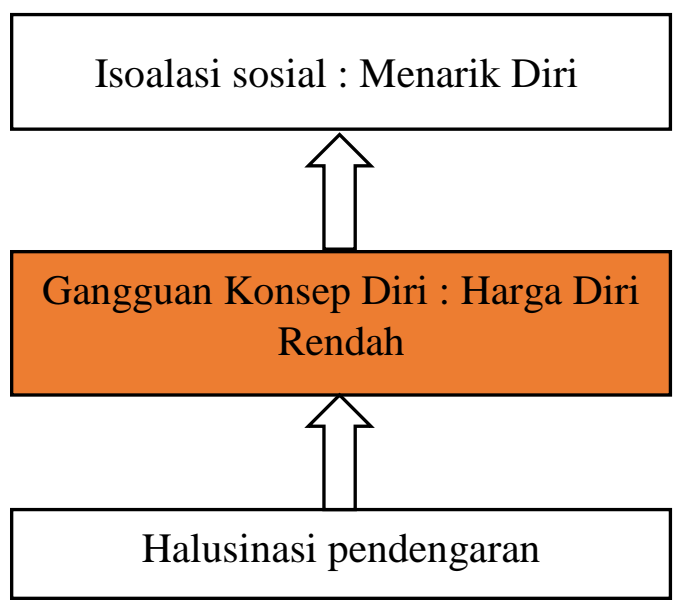

\subsection{Prioritas Diagnosa Keperawatan}

1. Gangguan Konsep Diri : Harga Diri Rendah

2. Gangguan Persepsi Sensori : Halusinasi pendengaran

3. Isolasi Sosial

\subsection{Intervensi}

\begin{tabular}{|c|c|}
\hline Diagnosa & Intervensi \\
\hline Harga Diri Rendah & $\begin{array}{l}\text { Sp } 1 \text { : } \\
\text { Mengindentifikasi kemampuan dan } \\
\text { aspek positif yang dimiliki pasien. } \\
\text { Sp } 2 \text { : } \\
\text { O Menilai kemampuan yang dapat } \\
\quad \text { di gunakan. } \\
\text { O Menetapkan/ memilih kegiatan } \\
\quad \text { sesuai kemampuan. } \\
\text { O Melatih kegiatan sesuai } \\
\quad \text { kemampuan yang dipilih } 1 . \\
\text { Sp } 3 \text { : } \\
\text { Melatih kegiatan sesuai kemampuan } \\
\text { yang dipilih } 2 \\
\text { Sp } 4 \text { : } \\
\text { Melatih kegiatan sesuai kemampuan } \\
\text { yang dipilih } 3\end{array}$ \\
\hline
\end{tabular}




\begin{tabular}{|c|c|}
\hline $\begin{array}{l}\text { Gangguan persepsi sensori : } \\
\text { halusinasi pendengaran }\end{array}$ & $\begin{array}{l}\text { SP } 1 \\
\text { 1. Identifikasi halusinasi : isi, } \\
\text { frekuensi, waktu terjadi, situasi, } \\
\text { pencetus, perasaan, respon } \\
\text { 2. Jelaskan cara mengontrol } \\
\text { halusinasi minum meghardik, } \\
\text { Sp } 2 \\
\text { Mongontrol halusinasi dengan minum } \\
\text { obat secara teratur } \\
\text { Sp } 3 \\
\text { Mongontrol halusinasi dengan } \\
\text { bercakap-cakap dengan orang lain } \\
\text { Sp } 4 \\
\text { Mongontrol halusinasi dengan } \\
\text { kegiatan terjadwal }\end{array}$ \\
\hline Isolasi Sosial : Menarik Diri & $\begin{array}{l}\text { SP } 1 \\
\text { Menjelaskan keutungan dan kerugian } \\
\text { memiliki teman } \\
\text { Sp } 2 \\
\text { Melatih klien berkenalan dengan } 2 \\
\text { orang atau lebih } \\
\text { Sp } 3 \\
\text { Melatih bercapak - cakap sambil } \\
\text { melakukan kegiata harian } \\
\text { Sp } 4 \\
\text { Melatih berbicara sosial : memintah } \\
\text { sesuatu, berbelanja dan sebagainya }\end{array}$ \\
\hline
\end{tabular}


3.18 Implementasi

\begin{tabular}{|c|c|c|}
\hline $\begin{array}{c}\text { Hari/ } \\
\text { tanggal }\end{array}$ & Implementasi & Evaluasi \\
\hline $\begin{array}{l}\text { Jumat } \\
28 \\
\text { januari } \\
2022\end{array}$ & $\begin{array}{l}\text { 1. Data } \\
\text { Tanda dan gejala: } \\
\text { - Menilai diri negative/ } \\
\text { mengkritik diri } \\
\text { - Merasa malu karena masuk } \\
\text { rumah sakit jiwa } \\
\text { - Merasa tidak mampu menjadi } \\
\text { ibu yang baik karena takut } \\
\text { anaknya diejek anak orang gila. } \\
\text { - Kontak mata kurang } \\
\text { - Berbicara pelan dan lirih } \\
\text { 2. Diagnosa Keperawatan } \\
\text { Gangguan Konsep Diri : Harga } \\
\text { Diri Rendah } \\
\\
\text { 3. Tindakan Keperawatan } \\
\text { Sp 1: Mengidentifikasi } \\
\text { kemampuan dan aspek positif } \\
\text { yang dimiliki pasien } \\
\text { 4. RTL: } \\
\text { SP 2 }\end{array}$ & $\begin{array}{l}\text { S : } \\
\text { Klien merasa senang dan antusias } \\
\text { O : } \\
\text { Klien mampu Mengidentifikasi aspek positif yang dimiliki } \\
\text { pasien yaitu bernyanyi dan berdoa secara mandiri } \\
\text { A : Harga Diri Rendah (+) } \\
\text { P : } \\
\text { - Latih klien merapikan tempat tidur } 1 \times 1 \text { hari } \\
\text { - Latih klien menyapu bawah tempat tidur } 1 \times 1 \text { hari }\end{array}$ \\
\hline
\end{tabular}




\begin{tabular}{|c|c|c|}
\hline & $\begin{array}{l}\text { a. Menilai kemampuan yang dapat } \\
\text { digunakan } \\
\text { b. Menetapkan atau memilih } \\
\text { kegiatan sesuai kemampuan } \\
\text { c. Melatih kegiatan sesuai } \\
\text { kemampuan yang dipilih } 1\end{array}$ & \\
\hline $\begin{array}{l}\text { Sabtu } \\
29 \\
\text { januari } \\
2022\end{array}$ & $\begin{array}{l}\text { 1. Data } \\
\text { Tanda dan gejala: } \\
\text { - Menilai diri negative/ } \\
\text { mengkritik diri } \\
\text { - Merasa malu karena masuk } \\
\text { rumah sakit jiwa } \\
\text { - Merasa tidak mampu menjadi } \\
\text { ibu yang baik karena takut } \\
\text { anaknya diejek anak orang } \\
\text { gila. } \\
\text { - Kontak mata kurang } \\
\text { - Berbicara pelan dan lirih } \\
\text { 2. Diagnosa Keperawatan } \\
\text { Gangguan Konsep Diri : Harga } \\
\text { Diri Rendah } \\
\text { Tindakan Keperawatan } \\
\text { SP } 2 \\
\text { - Menilai kemampuan yang } \\
\text { dapat digunakan }\end{array}$ & $\begin{array}{l}\text { S: } \\
\text { Klien merasa senang dan antusias } \\
\text { O : } \\
\text { Klien mampu memilih dan melatih kegiatan sesuai kemampuan } \\
\text { yaitu membersihkan tempat tidur dengan mandiri } \\
\text { A : Harga Diri Rendah (+) } \\
\text { P : } \\
\text { - Latihan membersikan tempat tidur } 2 \times 1 \text { hari }\end{array}$ \\
\hline
\end{tabular}




\begin{tabular}{|c|c|c|}
\hline & $\begin{array}{l}\text { - Menetapkan atau memilih } \\
\text { kegiatan sesuai kemampuan } \\
\text { - Melatih kegiatan sesuai } \\
\quad \text { kemampuan yang dipilih } 1 \\
\text { 4. RTL: } \\
\text { Sp 3 : Melatih kegiatan sesuai } \\
\text { kemampuan yang dipilih 2 }\end{array}$ & \\
\hline $\begin{array}{l}\text { Senin, } \\
31 \\
\text { januari } \\
2022\end{array}$ & $\begin{array}{l}\text { 1. Data } \\
\text { Tanda dan gejala: } \\
\text { - Menilai diri negative/ } \\
\text { mengkritik diri } \\
\text { - Merasa malu karena masuk } \\
\text { rumah sakit jiwa } \\
\text { - Merasa tidak mampu menjadi } \\
\text { ibu yang baik karena takut } \\
\text { anaknya diejek anak orang gila. } \\
\text { - Kontak mata kurang } \\
\text { - Berbicara pelan dan lirih } \\
\text { 2. Diagnosa Keperawatan } \\
\text { Gangguan Konsep Diri : Harga } \\
\text { Diri Rendah } \\
\text { 3. Tindakan Keperawatan } \\
\text { Sp 3: Melatih kegiatan sesuai } \\
\text { kemampuan yang dipilih } 2\end{array}$ & $\begin{array}{l}\text { S : } \\
\text { Klien merasa senang dan antusias } \\
\text { O : Klien mampu melatih kegiatan sesuai kemampuan yaitu } \\
\text { menyapu rumah dan membersikan tempat tidur dengan mandiri } \\
\text { A : Harga Diri Rendah }(+) \\
\text { P : } \\
\text { - membersikan tempat tidur } 2 \times 1 \text { hari } \\
\text { - Membantu menyapu } 1 \times 1 \text { hari }\end{array}$ \\
\hline
\end{tabular}




\begin{tabular}{|c|c|c|}
\hline & \begin{tabular}{|l} 
4. RTL: \\
Sp 4 : Melatih kegiatan sesuai \\
kemampuan yang dipilih 3 \\
\end{tabular} & \\
\hline $\begin{array}{l}\text { Rabu } \\
02 \\
\text { februari } \\
2022\end{array}$ & $\begin{array}{l}\text { 1. Data } \\
\text { Tanda dan gejala: } \\
\text { - Menilai diri negative/ } \\
\text { mengkritik diri } \\
\text { - Merasa malu karena masuk } \\
\text { rumah sakit jiwa } \\
\text { - Merasa tidak mampu menjadi } \\
\text { ibu yang baik karena takut } \\
\text { anaknya diejek anak orang gila. } \\
\text { - Kontak mata kurang } \\
\text { - Berbicara pelan dan lirih } \\
\text { 2. Diagnosa Keperawatan } \\
\text { Gangguan Konsep Diri : Harga } \\
\text { Diri Rendah } \\
\text { 3. Tindakan Keperawatan } \\
\text { Sp } 4 \text { : Melatih kegiatan sesuai } \\
\text { kemampuan yang dipilih } 3 \\
\text { 4. RTL : }\end{array}$ & $\begin{array}{l}\text { S : Senang dan Antusias } \\
\text { O : Melatih kegiatan sesuai kemampuan yang dipilih yaitu } \\
\text { menyapu rumah dengan mandiri } \\
\text { A : Harga diri rendah (-) } \\
\text { P : } \\
\text { - membersihkan tempat tidur } 2 \times 1 \text { hari } \\
\text { - Menyapu dibawah tempat tidur } 2 \times 1 \text { hari }\end{array}$ \\
\hline $\begin{array}{l}\text { Kamis } \\
03 \\
\text { fabruari } \\
2022\end{array}$ & \begin{tabular}{|l} 
1. Data \\
Tanda dan gejala : \\
- Menarik diri \\
- Menolak melakukan interaksi
\end{tabular} & $\begin{array}{l}\text { S : Senang dan Antusius } \\
\mathrm{O}:\end{array}$ \\
\hline
\end{tabular}




\begin{tabular}{|c|c|c|}
\hline & $\begin{array}{l}\text { - } \quad \text { Tidak bergairah dan lesu } \\
\text { - } \text { Merasa tidak diterima } \\
\text { 2. Diagnosa Keperawatan } \\
\text { Isolasi Sosial } \\
\text { 3. Tindakan Keperawatan } \\
\text { Sp1 : Menjelaskan keuntungan } \\
\text { dan kerugian mempunyai teman } \\
\text { 4. RTL: } \\
\text { Sp } 2 \text { : Melatih klien berkenalan } \\
\text { dengan } 2 \text { orang atau lebih }\end{array}$ & $\begin{array}{l}\text { - Pasien belum mampu mengenali masalah isolasi sosial } \\
\text { dengan mandiri. } \\
\text { - Mengidentifikasi isolasi sosialnya ; tanda dan gejala, } \\
\text { penyebab dan akibat dari isolasi sosial } \\
\text { - Pasien belum mampu menjelaskan keuntungan memiliki } \\
\text { teman dan kerugian memiliki teman dengan mandiri. } \\
\text { A : Isolasi Sosial (+) } \\
\text { - Melatih klien bercakap - cakap dengan orang lain } 3 \times 1 \text { hari } \\
\text { - Membersihkan tempat tidur } 1 \times 1 \text { hari }\end{array}$ \\
\hline $\begin{array}{l}\text { Jumat, } 04 \\
\text { februari } \\
2022\end{array}$ & $\begin{array}{l}\text { 1. Data } \\
\text { Tanda dan gejala : } \\
\text { - Menarik diri } \\
\text { - } \text { Menolak melakukan interaksi } \\
\text { - } \quad \text { Tidak bergairah dan lesu } \\
\text { - } \quad \text { Merasa tidak diterima } \\
\text { 2. Diagnosa Keperawatan } \\
\text { Isolasi Sosial }\end{array}$ & $\begin{array}{l}\text { S : Senang dan Antusias } \\
\text { O : } \\
\text { - Klien mampu menjelaskan cara berkenalan dengan bantuan } \\
\text { - Klien mampu mendemostrasikan cara berkenalan dengan } \\
\text { dimotivasi oleh perawat. }\end{array}$ \\
\hline
\end{tabular}




\begin{tabular}{|c|c|c|}
\hline & $\begin{array}{l}\text { 3. } \text { Tindakan Keperawatan } \\
\quad \text { Sp } 2 \text { : Melatih klien berkenalan } \\
\quad \text { dengan } 2 \text { orang atau lebih teman } \\
\text { 4. RTL: } \\
\text { Sp } 3 \text { : Melatih bercakap-cakap sambil } \\
\text { melakukan kegiatan harian }\end{array}$ & $\begin{array}{l}\text { - Klien mampu mempratekkan dan melakukan cara berkenalan } \\
\text { kepada perawat, teman dan orang lain dengan cara bantuan. } \\
\text { A : } \\
\text { Isolasi Sosial (+). } \\
\text { P : } \\
\text { - Latihan cara berkenalan } 1 \times 1 \text { hari } \\
\text { - Mendemostrasikan cara berkenalan } 1 \times 1 \text { hari } \\
\text { - Latih klien berkenalan dengan satu orang, dua orang, tiga } \\
\text { orang atau lebih } 3 x 1 \text { hari }\end{array}$ \\
\hline $\begin{array}{l}\text { Sabtu, } 05 \\
\text { februari } \\
2022\end{array}$ & $\begin{array}{l}\text { 1. Data } \\
\text { Tanda dan gejala : } \\
\text { - } \text { Menarik diri } \\
\text { - } \text { Menolak melakukan interaksi } \\
\text { - } \text { Tidak bergairah dan lesu } \\
\text { - } \quad \text { Merasa tidak diterima } \\
\text { 2. Diagnosa Keperawatan } \\
\text { Isolasi Sosial }\end{array}$ & $\begin{array}{l}\text { S : Senang dan Antusias } \\
\text { O : } \\
\text { - Klien mampu menjelaskan cara berkenalan dengan bantuan. } \\
\text { - Klien mampu Mendemostrasikan cara } \\
\text { - berkenalan dengan dimotivasi oleh perawat. } \\
\text { - Klien mampu mempratekkan dan melakukan cara } \\
\text { berkenalan kepada perawat, teman dan orang lain. }\end{array}$ \\
\hline
\end{tabular}




\begin{tabular}{|c|c|c|}
\hline & $\begin{array}{l}\text { 3. Tindakan Keperawatan } \\
\text { Sp } 3 \text { : Melatih bercakap-cakap } \\
\text { sambil melakukan kegiatan harian } \\
\text { 4. RTL: } \\
\text { Sp } 4 \text { : } \\
\text { Melatih berbicara sosial : } \\
\text { meminta sesuatu belanja dan } \\
\text { sebagainya }\end{array}$ & $\begin{array}{l}\text { A : } \\
\text { Isolasi Sosial }(+) \\
\text { P : } \\
\text { - Latihan cara berkenalan } 1 \times 1 \text { hari } \\
\text { - Mendemostrasikan cara berkenalan } 2 \times 1 \text { hari }\end{array}$ \\
\hline $\begin{array}{l}\text { Senin, } 07 \\
\text { februari } \\
2022\end{array}$ & $\begin{array}{l}\text { 1. Data } \\
\text { Tanda dan gejala : } \\
\text { - Menarik diri } \\
\text { - Menolak melakukan interaksi } \\
\text { - } \text { Tidak bergairah dan lesu } \\
\text { - Merasa tidak diterima } \\
\text { 2. Diagnosa Keperawatan } \\
\text { Isolasi Sosial } \\
\text { 3. Tindakan Keperawatan } \mathrm{Sp} 4: \\
\text { Melatih berbicara sosial : }\end{array}$ & $\begin{array}{l}\text { S : Senang dan Antusius } \\
\text { O : } \\
\text { - Klien mampu mempraktekkan cara bercakap-cakap dengan } \\
\text { orang lain saat melakukan kegiatan dengan mandiri. } \\
\text { - Klien mampu bersosialisasi meminta sesuatu dengan } \\
\quad \text { mandiri. } \\
\text { A : } \\
\text { Isolasi Sosial (-) } \\
\text { P : }\end{array}$ \\
\hline
\end{tabular}




\begin{tabular}{|c|c|c|}
\hline & $\begin{array}{l}\text { meminta sesuatu belanja dan } \\
\text { sebagainya } \\
\text { 4. } \\
\text { RTL: } \\
\text { Isolasi Sosial : Follow up dan } \\
\text { evaluasi Sp 1-4 Isolasi sosial }\end{array}$ & $\begin{array}{l}\text { - Latihan bercakap-cakap sambil melakukan kegiatan harian } \\
\text { - } 3 \times 1 \text { hari } \\
\text { - Latihan berbicara sosial } \\
\text { - Latihan meminta sesuatu } 3 \times 1 \text { hari } \\
\text { - Latihan bercakap-cakap dengan orang lain } 3 \times 1 \text { hari }\end{array}$ \\
\hline $\begin{array}{l}\text { Selasa, } \\
08 \\
\text { februari } \\
2022\end{array}$ & $\begin{array}{l}\text { 1. Data } \\
\text { Tanda dan gejala : } \\
\text { - Mendengar suara-suara } \\
\text { mengatakan "memanggil } \\
\text { namanya dan mengatakan nak } \\
\text { lagi ngapain" suara mirip } \\
\text { suara ibunya } \\
\text { - Tertawa sendiri } \\
\text { - } \text { Berbicara sendiri } \\
\text { 2. Diagnosa Keperawatan } \\
\text { Husinasi pendengaran } \\
\text { 3. Tindakan Keperawatan } \\
\text { Sp1 halusinasi } \\
\text { 1. Melatih pasien } \\
\text { mengidentifikasi }\end{array}$ & $\begin{array}{l}\text { S: } \\
\text { Senang } \\
\text { O: } \\
\text { klien masih mendengar suara - suara biskan tampak mengerti } \\
\text { tentang minum obat secara teratur } \\
\text { A: Halusinasi pendengara (+) } \\
\text { P: } \\
\text { - Latihan menghardik halusinasi } 3 \times 1 \text { hari } \\
\text { - Latihan klien merapikan tempat tidur } 1 \times 1 \text { hari }\end{array}$ \\
\hline
\end{tabular}




\begin{tabular}{|c|c|c|}
\hline & $\begin{array}{l}\text { halusinasinya; isi, frekuensi, } \\
\text { watu terjadi, sruasi pencetus, } \\
\text { perasaan dan respon } \\
\text { halusinasi } \\
\text { 2. Mengontrol halusinasi dengan } \\
\text { cara menghardik } \\
\text { 4. RTL } \\
\text { Sp2; mengontrol halusinasi } \\
\text { dengan cara minum obat } \\
\text { Sp3; mengontrol halusinasi } \\
\text { dengan cara bercakap - cakap }\end{array}$ & \\
\hline $\begin{array}{l}\text { rabu, } 09 \\
\text { februari } \\
2022\end{array}$ & $\begin{array}{l}\text { 1. Data } \\
\text { Tanda dan gejala : } \\
\text { - } \text { Mendengar suara-suara } \\
\text { mengatakan "memanggil } \\
\text { namanya dan mengatakan nak } \\
\text { lagi ngapain" suara mirip } \\
\text { suara ibunya } \\
\text { - } \quad \text { Tertawa sendiri } \\
\text { - } \\
\text { Berbicara sendiri }\end{array}$ & $\begin{array}{l}\text { S: } \\
\text { Senang dan Antusias } \\
\text { O: } \\
\text { 1. klien mampu mengontrol halusinasi dengan minum obat } \\
\quad \text { secara teratur dengan bantuan pengawas yayasan. } \\
\text { 2. Klien mampu melakukan komunikasi secara verbal : } \\
\quad \text { asertif/bicara baik-baik dengan motivasi. } \\
\text { A : } \\
\text { Halusinasi pendengara }(+)\end{array}$ \\
\hline
\end{tabular}




\begin{tabular}{|c|c|c|}
\hline & $\begin{array}{l}\text { 2. Diagnosa keperawatan } \\
\text { Halusinasi pendengaran } \\
\text { 3. Tindakan keperawatan } \\
\text { Sp2 : } \\
\text { Memberikan informasi tentang } \\
\text { cara pengunaan obat minum } \\
\text { obat } \\
\text { Sp3 : } \\
\text { memberikan informasi dampak } \\
\text { positif mengontol halusinasi } \\
\text { dengan cara bercakap - cakap } \\
\text { 4. RL : } \\
\text { Sp4 : } \\
\text { Mengontrol halusinasi dengan } \\
\text { cara melakukan aktivitas }\end{array}$ & $\begin{array}{l}\text { P: } \\
\text { - Latihan menghardik halusinasi } 3 \times 1 \text { hari } \\
\text { - Latihan minum obat dengan prinsip } 6 \text { benar } 2 \times 1 \text { hari }\end{array}$ \\
\hline $\begin{array}{l}\text { Kamis, } \\
10 \\
\text { februari } \\
2022\end{array}$ & 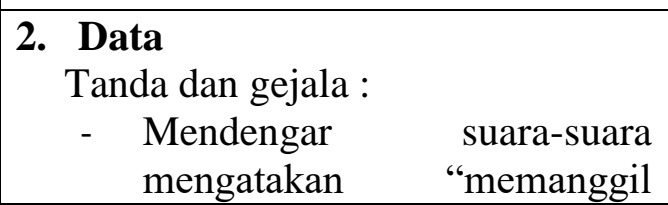 & $\begin{array}{l}\text { S : } \\
\text { Senang dan antusias } \\
\mathrm{O}:\end{array}$ \\
\hline
\end{tabular}




\begin{tabular}{|c|c|}
\hline $\begin{array}{l}\text { namanya dan mengatakan nak } \\
\text { lagi ngapain" suara mirip } \\
\text { suara ibunya } \\
\text { - } \quad \text { Tertawa sendiri } \\
\text { - } \text { Berbicara sendiri } \\
\text { 2. Diagnosa keperawatan } \\
\text { Halusinasi pendengaran } \\
\text { 3. Tindakan keperawatan } \\
\text { Sp4 : Halusinasi } \\
\text { Mengontrol halusinasi dengan } \\
\text { melakukan kegiatan terjadwal } \\
\text { 4. RTL : } \\
\text { Halusinasi : Follow up dan } \\
\text { evaluasi Sp 1-4 Halusinasi }\end{array}$ & $\begin{array}{l}\text { Klien mempraktekkan cara bercakap-cakap dengan orang lain } \\
\text { A : } \\
\text { Halusinasi pendengaran (-) } \\
\text { P : } \\
\text { - Latihan menghardik halusinasi } 3 \times 1 \text { hari } \\
\text { - Latihan minum obat dengan prinsip } 6 \text { benar } 2 \times 1 \text { hari } \\
\text { - Latihan bercakap-cakap dengan orang lain } 3 \times 1 \text { hari } \\
\text { - Anjurkan klien berdoa } 2 \times 1 \text { hari }\end{array}$ \\
\hline
\end{tabular}




\section{BAB 4}

\section{PEMBAHASAN}

Setelah penulis melaksanakan Asuhan Keperawatan Jiwa Pada Tn. A Dengan Harga Diri Rendah di Rumah Sakit Prof. Dr. M. Ildrem maka penulis pada BAB ini akan membahasan kesenjangan antara teoritis dengan tinjauan kasus. Pembahasan dimulai melalui tahapan proses keperawatan yaitu pengkajian, diagnosa keperawatan, perencanaan, pelaksanaan dan evaluasi.

\subsection{Tahap Pengkajian}

Selama pengkajian dilakukan pengumpulan data dari beberapa sumber, yaitu dari pasien dan tenaga kesehatan di rumah sakit jiwa. Penulis mendapat sedikit kesulitan dalam menyimpulkan data karena keluarga pasien tidak pernah mengunjungi pasien di rumah sakit jiwa. Maka penulis melakukan pendekatan kepada pasien melalui komunikasi teraupetik yang lebih terbuka membantu klien untuk memecahkan perasaannya dan juga melakukan observasi kepada pasien. Adapun upaya tersebut yaitu:

1. Melakukan pendekatan dan membina hubungan saling percaya diri pada klien agar klien lebih terbuka dan lebih percaya dengan menggunakan perasaan.

2. Mengadakan pengkajian klien dengan wawancara

3. Mengadakan pengkajian bertanya kepada pegawai rumah sakit jiwa yang ada di ruangan.

Dalam pengkajian ini, penulis tidak menemukan kesenjangan karena ditemukan hal sama seperti diteori: Mengkritik diri sendiri, perasaan tidak mampu, pandangan hidup yang pesimis, penurunan produktivitas, penolakan terhadap kemampuan diri, malu terhadap diri sendiri, bicara ngawur, suka menyendiri, kontak mata kurang (Pardede, 2019). 


\subsection{Diagnosa Keperawatan}

Diagnosis keperawatan ialah identifikasi atau penilaian terhadap pola respons klien baik actual maupun potensial dan merupakan dasar pemilihan intervensi dalam mencapai tujuan yang telah di tetapkan oleh perawat yang bertanggung jawab. Data-data yang mendukung analisa data menurut (Keliat, 2015):

1. Harga Diri Rendah

2. Isolasi Sosail

3. Halusinasi Pendengara

\subsection{Tahap Perencanaan}

Perencanaan dalam proses keperawatan lebih dikenal dengan rencana asuhan keperawatan yang merupakan tahap selanjutnya setelah pangkajian dan penentuan diagnosa keperawatan. Pada tahap perencanaan penulis hanya menyusun rencana tindakan keperawatan sesuai dengan pohon masalah keperawatan yaitu: Gangguan Konsep Diri: Harga diri rendah

Pada tahap ini antara tinjauan teoritis dan tinjauan kasus tidak ada kesenjangan sehingga penulis dapat melaksanakan tindakan seoptimal mungkin dan didukung dengan tersedianya sarana ruangan perawat yang baik dan adanya bimbingan dan petunjuk dari petugas kesehatan dari rumah sakit jiwa yang diberikan kepada penulis. Secara teoritis digunakan cara strategi pertemuan sesuai dengan diagnosa keperawatan yang muncul saat pengkajian. Adapun upaya yang dilakukan penulis yaitu:

Gangguan Konsep Diri: Harga diri rendah

1. Harga diri rendah

Sp1: indentifikasi kemampuan dan aspek positif yang di miliki

Sp2 :

- Menilai dan menetapkan kemampuan yang dapat digunakan

- Menetapkan atau memilih kemapuan yang dapat digunakan

- Melatih kempuan yang dapat digunakan 1 
Sp 3 : melatih kegiatan yang dapat digunakan 2

Sp 4 : melatih kegiatan yang dapat digunakan 3

2. Isolasi Sosial

SP 1 : Menjelaskan keutungan dan kerugian memiliki teman

Sp 2 : Melatih klien berkenalan dengan 2 orang atau lebih

Sp 3 : Melatih bercapak - cakap sambil melakukan kegiata harian

Sp 4 : Melatih berbicara sosial : memintah sesuatu, berbelanja dan sebagainya

3. Halusinasi Pendengaran

Sp1:

- Indentifikasiisi, waktu terjadi, situasi pencetus, perasaan dan respon halusinasi

- Mengontrol halusinasi dengan menghardik

Sp2 :mongontrol halusinasi dengan minum obat secara teratus

Sp3:komunikasi secara verbal: asertif / bicara baik-baik

Sp4 : spiritual

\section{Tahap Implementasi}

Pada tahap implementas penulis hanya mengatasi masalah keperawatan dengan diagnosa keperawatan Gangguan Konsep Diri : Harga diri rendah . Pada diagnosa keperawatan Gangguan Konsep Diri : Harga diri rendah dilakukan strategi pertemuan yaitu mengidentifikasi kemampuan dan aspek positif yang dimiliki pasien, menilai kemampuan yang dapat digunakan menetapkan/memilih kegiatan sesuai kemampuan "melatih kegiatan sesuai kemampuan yang dipilih 1”, melatih kegiatan sesuai kemampuan yang dpilih 2, dan melatih kegiatan sesuai kemampuan yang di pilih 3. (Pardede, Keliat, \& Yulia, 2015).

\section{Tahap Evaluasi}

Setelah tindakan keperawatan, segera lakukan evaluasi. Evaluasi terhadap masalah keperawatan harga diri rendah meliputi kemampuan pasien harga diri rendah dan 
keluarganya dan kemampuan perawat dalam merawat pasien harga diri rendah (Tobing, Keliat \& Wardhani, 2015). Pada tinajauan teoritis evaluasi yang diharapkan adalah: Pasien mempercayai perawat sebagai terapi, pasien menyadari bahwa pasien memiliki kemampuan dan aspek yang dimiliki. Klien mampu mengindentifikasi kemampuan yang dimiliki, Klien mampu menilai, menetapkan dan melatih kegiatan sesuai kemampuan yang dipilih :

1. Strategi pertemuan selanjutnya yaitu Strategi pertemuan selanjutnya yaitu melatih kegiatan sesuai kemampuan yang dipilih.

2. Klien mampu melaksanakan jadwal yang telah dibuat bersama, Klien mampu melatih kegiatan sesuai kemampuan yang dipilih.

3. Selain itu, dapat dilihat dari setiap evalusi yang dilakukan pada asuhan keperawatan, dimana terjadi penurunan gejala yang dialami oleh Tn. A dari hari kehari selama proses interaksi 


\section{BAB 5 \\ PENUTUP}

\subsection{Kesimpulan}

Berdasarkan konsep asuhan keperawatan yang telah disusun dan dilaksanakan kepada Tn.A dimiliki dari pengkajian, rumusan masalah, perencanaan, pelaksanaan hingga evaluasi didapat hasil bahwa Tn.A dengan keluhan utama klien berbicara sendiri, berkelakukan aneh, melukai diri sendiri, tidak bisa tidur, merasa malu dan menyesal dengan keadaan nya sekarang. Objektif yaitu klien tampak berdiam diri, bingung dan terkadang menunduk. Dari masalah masalah diatas maka diperoleh prioritas masalah yang diangkat adalah tentang Harga Diri Rendah. Kemudian diberikan intervensi secara konsep yaitu melatih kegiatan yang dipilih. Dari hasil implementasi ada beberapa intervensi yang berhasil teratasi seperti klien sudah mulai mau untuk megatakan penyakitnya yang sebenarnya, klien mampu membuka diri pada keluarga, Tetapi kelien masih sedikit malu.

\subsection{Saran}

Diharapkan bagi perawat selalu berkoordinasi dengan tenaga kesehatan lainnya dalam memberikan asuhan keperawatan agar lebih maksimal terkusus pada klien dengan Harga Diri Rendah pada pasien Skinzofrenia. 


\section{DAFTAR PUSTAKA}

1. Depkes. (2019). Pedoman nasional penanggulangan tuberkulosis, Edisi 2. Jakarta.

2. Elvidiana, H., \& Fitriani, D. R. (2019). Analisis Praktik Klinik Keperawatan pada Ibu $R$ dengan Harga Diri Rendah dengan Intervensi Inovasi Logoterapi Terhadap Gangguan Harga Diri Rendah di Ruang Punai RSJD Atma Husada Mahakam Samarinda..

3. Pardede, J. A., Keliat, B. A., \& Wardani, I. Y. (2020). The Symptoms of Low Self-Esteem Decline after Being Given Acceptance and Commitment Therapy. Adv Practice Nurs, 5, 170.

4. Pardede, J. A., Damanik, R. K., Simanullang, R. H., \& Sitanggang, R. (2020). The Effect Of Cognitive Therapy On Changes In Self-Esteem On Schizophrenia Patients. European Journal of Molecular \& Clinical Medicine, 7(11),

5. Pardede, J. A. (2020). Decreasing Hallucination Response Through Perception Stimulation Group Activity Therapy In Schizophrenia Patients. Iar Journal of Medical Sciences, 1(6), 304-309.

6. Kenedyanti, E., \& Sulistyorini, L. (2017). Analisis Mycobacterium Tuberkulosis Dan Kondisi Fisik Rumah dengan Kejadian Tuberkulosis Paru. Jurnal Berkala Epidemiologi, $\quad 5(2), \quad$ 152-162. https://doi.org/10.20473/jbe.v5i2.2017.152-162

7. Kemenkes RI. (2018). Riset Kesehatan Dasar, RISKESDAS.Jakarta: Kemenkes RI.

8. Kemenkes RI. (2020). Riset Kesehatan Dasar, RISKESDAS.Jakarta: Kemenkes RI.

9. Kholifah, Nurul, S.,\& Indreswari, S.A. (2015). Faktor Terjadinya Tuberkulosis Paru pada Anak Berdasarkan Riwayat Kontak Serumah Vol 14, Nomor 2. Semarang: Jurnal Kesehatan Masyarakat. Fakultas Kesehatan Universitas Dian Nuswantoro. Di akses dari https://publikasi.dinus.ac.id/index.ph p/visikes/article/view/1203.

10. Noviyani, E., Fatimah, S., Nurhidayah, I., \& Adistie, F. (2015). Upaya Pencegahan Penularan TB dari Dewasa terhadap Anak, Vol 3 Nomor 2. 
Bandung:Jurnal Keperawatan Padjajaran Fakultas Keperawatan Universitas Padjadjaran. Di Akses dari jkp.fkep.unpad.ac.id.

11. Pardede, J. A., Keliat, B. A., \& Yulia, I. (2015). Kepatuhan Dan Komitmen Klien Skizofrenia Meningkat Setelah Diberikan Acceptance And Commitment Therapy Dan Pendidikan Kesehatan Kepatuhan Minum Obat. Jurnal Keperawatan Indonesia, 18(3), 157-166. Http://Jki.Ui.Ac.Id/Index.Php/Jki/Article/View/419

12. Pardede, J. A., Hafizuddin, H., \& Sirait, A. (2021). Coping Strategies Related to Self-Esteem on PLWHA in Medan Plus Foundation. Jurnal Ilmu Keperawatan Jiwa, 4(2), 255-262.

13. Pardede, J. A., Harjuliska, H., \& Ramadia, A. (2021). Self-Efficacy dan Peran Keluarga Berhubungan dengan Frekuensi Kekambuhan Pasien Skizofrenia. Jurnal Ilmu Keperawatan Jiwa, 4(1), 57-66. http://dx.doi.org/10.32584/jikj.v4i1.846

14. Pardede, J. A., Hutajulu, J., \& Pasaribu, P. E. (2020). Harga Diri dengan Depresi Pasien Hiv/aids. Jurnal Media Keperawatan: Politeknik Kesehatan Makassar, 11(01). https://doi.org/10.32382/jmk.v11i1.1538

15. Pardede, J. A., Huda, A., Saragih, M., \& Simamora, M. (2021). Verbals Bullying Related To Self-Esteem On Adolescents. Jendela Nursing Journal (JNJ), 5(1), 16-22. https://doi.org/10.31983/jnj.v5i1.6903

16. Pardede, J. A. (2017). The Implementation of Family Tasks with The Frequency of Recurrence of Social Isolation Patients. Mental Health, 4(2).

17. Pardede, J. A., Simamora, M., \& Simanjuntak, G. V. (2020). Family Support and Self-Esteem of Patient with Breast Cancer Education, 25(6), 735.https://www.easpubliher.com/easjnm

18. Rahayu, S., Mustikasari, M., \& Daulima, N. H. (2019). Perubahan Tanda Gejala dan Kemampuan Pasien Harga Diri Rendah Kronis Setelah Latihan Terapi Kognitif dan Psikoedukasi Keluarga. JOURNAL EDUCATIONAL OF NURSING (JEN), 2(1), 39-51. https://doi.org/10.37430/jen.v2i1.10

19. Samosir, E. F. (2020). Penerapan Asuhan Keperawatan Jiwa Pada An . A Dengan Gangguan Konsep Diri : Harga Diri Rendah Di Lingk . XVI Lorong Jaya. 1-41.

20. Suprapto, S. (2018). Pengetahuan Dan Sikap Masyarakat Dalam Upaya Pencegahan Tuberkulosis Di Wilayah Kerja Puskesmas Batua Kota Makassar. Jurnal Ilmiah Kesehatan Sandi Husada, 1114-1124. 
https://doi.org/10.35816/jiskh.v6i1.10

21. Suryani, U., \& Efendi, Z. (2020). Dukungan Keluarga Berhubungan dengan Harga Diri pada Penderita Tuberkulosis Paru. Jurnal Ilmu Keperawatan Jiwa, 3(1), 53. https://doi.org/10.32584/jikj.v3i1.474

22. Lete, G. R., Kusuma, F. H. D., \& Rosdiana, Y. (2019). Hubungan Antara Harga Diri Dengan Resiliensi Remaja Di Panti Asuhan Bakti Luhur Malang. Nursing News: Jurnal Ilmiah Keperawatan, 4(1). Https://Publikasi.Unitri.Ac.Id/Index.Php/Fikes/Article/View/1436

23. Wandono, W. A., \& Arum Pratiwi, S. (2017). Upaya peningkatan harga diri rendah pada pasien depresi (Doctoral dissertation, Universitas Muhammadiyah Surakarta). http://eprints.ums.ac.id/id/eprint/52383

24. Widhaswari, D. O. (2017). Asuhan keperawatan psikososial harga diri rendah situasional pada klien dengan diabetes mellitus dan luka gangren di Ruang Antasena RS DR. H. Marzoeki Mahdi Bogor

25. Wilkinson, J.M., \& Ahern, N. R. (2009). Buku saku diagnosis keperawatan. Edisi 9. Jakarta: EGC.

26. Wijayati, F., Nasir, T., Hadi, I., \& Akhmad, A. (2020). Faktor-Faktor yang Berhubungan dengan Kejadian Harga Diri Rendah Pasien Gangguan Jiwa. Health Information: Jurnal Penelitian, 12(2), 224-235 https://doi.org/10.36990/hijp.v12i2.234

27. Yusuf, A Dkk. (2015). Buku Ajar Keperawatan Kesehatan Jiwa. Jakarta Salemba Medika. 
